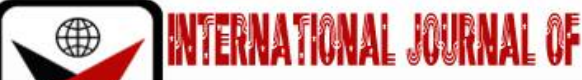

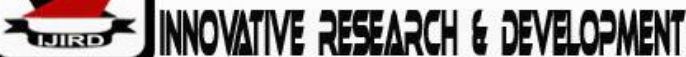

ISSN 2278-0211 (Online)

\section{Evaluation of the Antidiabetic and Associated Effect of Methanol Root Extract of Strophanthushispidus DC (Apocynaceae) on Alloxan-Induced Diabetic Rats}

\author{
Odoh Uchenna Estella
Professor, Department of Pharmaceutical and Medicinal Chemistry,
University of Nigeria, Nsukka, Nigeria
Osadebe, Patience Ogoamaka
Professor, Department of Pharmaceutical and Medicinal Chemistry,
University of Nigeria, Nsukka, Nigeria
Abudu Cletus
Student, Department of Pharmacognosy and Environmental Medicines,
University of Nigeria, Nsukka, Nigeria
}

\begin{abstract}
:
The antidiabetic properties of the methanol root extract of Strophanthus hispidus DC (Apocynaceae) was evaluated on normoglycaemic and hyperglycaemic rats. Diabetes was induced in rats using alloxan (150mg/kg body weight intraperitoneally). Normoglycaemic and hyperglycaemic rats were administered orally with single doses of (200, 400 and $800 \mathrm{mg} / \mathrm{kg}$ ) the root extract of Strophanthus hispidus, $5 \mathrm{mg} / \mathrm{kg}$ of Glibenclamide (positive control) and distilled water (negative) control for 14 days. The blood sugar level was determined using Glucometer. The acute toxicity (LD $\left.D_{50}\right)$ test of methanol root extract was determined. The effect of the extract on some pathological parameters and the phytochemical constituents were also investigated. The root extract produced a dose reduction $(P<0.05)$ in blood sugar levels of both normoglycaemic and hyperglycaemic rats. When doses of 200, 400 and $800 \mathrm{mg} / \mathrm{kg}$ of the extract were administered orally to alloxan induced diabetic rats, significant reduction in blood sugar level occurred (64.72, 67.69 and $69.43 \%$ respectively) while Glibenclamide caused a $67.74 \%$ reduction. In normal rats, the extract (200, 400 and $800 \mathrm{mg} / \mathrm{kg}$ ) exhibited a significant reduction of the blood sugar level of 27.59, 34.28 and $41.92 \%$ respectively, while Glibenclamide caused a 39.78\% reduction. Phytochemical analysis on Strophanthus hispidus showed the presence of alkaloids, flavonoids, carbohydrates, tannins, terpenoids, reducing sugars, steroids, proteins, glycosides and saponins. Acute toxicity test carried out in mice using Lorke's method showed that the root extract was relatively safe, since no death was recorded at the dose $5000 \mathrm{mg} / \mathrm{kg}$. There was significant $(p<0.05)$ increase in the liver enzymes level in the diabetic rats on day 0 before the administration of the extract. At day 14 in the alloxan-induced diabetic rats, there was a significant $(p<0.05)$ decrease in the liver enzymes at studied doses $(200,400$ and $800 \mathrm{mg} / \mathrm{kg}) \mathrm{when}$ compared to the normal. There was significant $(p<0.05)$ difference in the AST level at day 14 when compared to day 0 in alloxan-induced diabetic rats. At the doses extract, there was a significant decrease in the ALP level when compared to the normal at day 0. Also, the extract has the effect of decreasing the urea level at a dose of $200,400 \mathrm{and} 800 \mathrm{mg} / \mathrm{kg}$ from 36.35, 40.95 and $41.00 \mathrm{mg} / \mathrm{dl}$ at day 0 to $17.60,16.31$ and $14.60 \mathrm{mg} / \mathrm{dl}$ at day 14 . The level was similarly reduced for the positive group (Glibenclamide). At day 14 there was a decrease in the urea level in the diabetic rats when compared to day 0 . The methanol root extract has no significant effect in the creatinine level. The study shows that the root extract of Strophanthus hispidus has a significant hypoglycaemic activity in normoglycaemic and alloxan-induced diabetic rats. Similarly, the extract does possess hepatoprotective effect in alloxan-induced diabetic rats.
\end{abstract}

Keywords: Strophanthus hispidus, diabetes mellitus, phytochemical analysis, acute toxicity, hyperglyceamic

\section{Introduction}

Diabetes mellitus (DM) also known as simply diabetes, is a group of metabolic diseases in which there are high blood sugar levels over a prolonged period. This high blood sugar produces the symptoms of frequent urination, increased thirst, and increased hunger. There are three main types of diabetes mellitus: Type 1 diabetes mellitus, Type 2 diabetes mellitus and Gestational diabetes mellitus (WHO, 2013). This type of diabetes is also referred to as non-insulin dependent diabetes mellitus (NIDDM) or adult-onset diabetes is a metabolic disorder that is characterized by hyperglycemia in the context of insulin resistance and relative lack of insulin. This is in contrast to diabetes mellitus type1, in which there is an absolute lack of insulin due to breakdown of islet cells in the pancreas (Kumar et al., 2005). The classic symptoms are excess thirst, frequent urination and constant hunger. Type 2 diabetes make up about $90 \%$ of cases of diabetes, with the 
other $10 \%$ due primarily to diabetes mellitus type 1 and gestational diabetes. Obesity is thought to be the primary cause of Type 2 diabetes in people who are genetically predisposed to the disease (David et al., 2011). Type 2 diabetes is initially managed by increasing exercise and dietary changes. Long-term complications from high blood sugar can include heart disease, stroke, diabetes retinopathy where eyesight is affected and kidney failure (Symths et al., 2006).

Plants have been shown to have antidiabetic properties and have been used in traditional medicines in management of diabetes mellitus (Osadebe et al., 2014). Some medicinal plants with investigated antidiabetic potentials include; Ceiba pentandra ( Odoh et al., 2016), Acalypha wilkesiana ( Odoh et al., 2014),Acanthus montanus(Odoh et al., 2013), Abelmoschus moschatus(Liu et al., 2007),, Carum carvi (Eddouks et al., 2004), Acacia Arabica (Yasir et al., 2010), Allium cepa (Eidi et al., 2006), Andrographis paniculata (Dandu and Inamdar, 2009), Aegle maarmelose (Seema et al., 1996), Azadirachata indica (Chattopadhyay, 1996), Brassica juncea (Thirumalai et al., 2003).

Strophanthus hispidus DC (Apocynaceae) is native to Guniea-Bissan, Guinea, Liberia, Burkina faso, Ivory Coast, Ghana, Togo, Benin, Cameroon, Gabon and also in Nigeria. It is a medicinal plant widely used in traditional African medicine in the treatment of rheumatic afflictions, ulcer, conjunctivitis, leprosy, skin disease, pain, inflammation and management of diabetes. The sole official use of strophanthus in medicine is for its influence on the circulation, especially in cases Arthritis, Stroke and heart failure (Ayoola et al., 2008). The root extract of Strophanthushispidus possesses antinociceptive, anti-inflammatory and antiulcerogenic activities (Ishola et al., 2013). This justifies the use of the extract in folklore medicine for the treatment of ulcer and inflammatory disorders. The study was to determine the anti-diabetic activity of the root of Strophanthus hispidus on alloxan-induced diabetic rats and its effect on some biochemical parameters associated complications of diabetes.

\subsection{Taxonomic Profile of Stronphanthus Hispidus DC \\ Kingdom: Plantae \\ Order: gentianales \\ Family: Apocynaceae \\ Genus: Strophanthus \\ Species: hispidus \\ Common names: arrow poison, brown strophanthus}

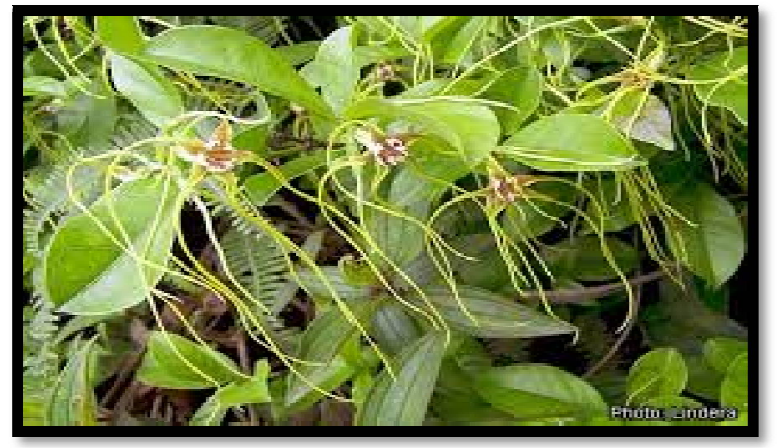

Figure 1: Picture of Stronphanthus Hispidus DC (Apocynaceae)

\section{Materials and Methods}

\subsection{Identification Collection and Preparation of Plant Materials}

The root of Strophanthus hispidus used in this study were collected from Mbaitolu in Imo State, Nigeria in July 2014. This plant material was identified and authenticated by Mr. Alfred Ozioko of International centre for Ethnomedicine and Drug Development (Inter CEDD), Nsukka.

The roots were washed carefully with water, cut into smaller pieces and allowed to dry under the shade. The cut dried roots were grinded into very fine powder and the powdered root sample was weighed using a weighing balance and the weight recorded.

\subsection{Animals Used}

White albino rats weighing 110-136g and mice weighing between 29-37g of either sex were used in the experiment. They were obtained from the Animal House of Zoology Department, University of Nigeria, Nsukka. The animals were kept in a standard condition and were given access to food and water before the experiment and after the induction of diabetes. Approval for the use of animal subjects was secured from the Animal Research Ethics Committee, University of Nigeria, Nsukka. The animals were handled according to International protocol for handling laboratory animals as documented in the European Community guideline, revised Council Directive, 2010/63/EU.

\subsection{Extraction}

A 700g of powdered root macerated at room temperature with 3 litres ofanalytical grade methanol for 3 days with intermittent shaking at interval. The extract was filtered and filtrate evaporated to dryness under reduced pressure using a rotary evaporator. The dried extract was collected and weighed and stored in the refrigerator from where portions were then taken for experiments. 


\subsection{Phytochemical Analysis of Extract}

Various phytochemical tests were carried out on the methanol extract of the root of Strophanthus hispidus following standard procedures (Trease and Evans, 1989) as described below:

\subsection{Determination of Acute Toxicity $\left(L D_{50}\right)$}

The acute toxicity test was carried out using Lorke's method (1983).Lethal dose $\left(\mathrm{LD}_{50}\right)$ is the minimum dose of a drug that can cause death in $50 \%$ of a given population of animals. This method of acute toxicity records the number of deaths per treatment groups of animals that occurred in 24 hours. The methanol extract of Strophanthus hispidus was dissolved in water for administration. The procedure was carried out in two stages.

In first stage, Nine(9) mice divided into three treatment groups of three (3) animals per groups were used. Doses of 10, 100 , and $1000 \mathrm{mg} / \mathrm{kg}$ body weight of the methanol extract were administered to group one, two and three respectively and the animals were observed for $24 \mathrm{~h}$ for any death. In the second stage, six (6) mice divided into three treatment groups of two animals per group were used. Doses of $1600,2900 \mathrm{and} 5000 \mathrm{mg} / \mathrm{kg}$ of the methanol extract were administered to group one, two and three respectively and thereafter observed for 24 hours for any death.

\subsection{Pharmacological Evaluation}

\subsubsection{Induction of Diabetes}

Twenty-five (25) white albino rats were used for the study. They were fed with commercial fowl feed and allowed free access to water. The basal blood glucose level of the rats was taken before induction of diabetes by collecting blood sample from the tail vein of the rats and the blood glucose concentration determined using Accu-check glucometer. Diabetes was induced by intraperitoneal administration of $150 \mathrm{mg} / \mathrm{kg}$ body weight of alloxan monohydrate freshly prepared in normal saline. Thereafter the animals were fed normally with feed and water and after 3 days of induction, animals with fasting blood glucose level of $200 \mathrm{mg} / \mathrm{dl}$ and above were considered diabetic (Odoh et al., 2014).

\subsubsection{Determination of the Anti-Diabetic Effect of the Methanol Root Extract of Strophanthus Hispidus on the Fasting} Blood Sugar Level of Normoglycemic Rats

Twenty-five (25) healthy albino rats divided into five groupsof five animals each were used for the experiment. They were fasted overnight for $12 \mathrm{hrs}$.and at the end of the fasting period, different doses of the extract were given to the animals orally.Group 1 receive $200 \mathrm{mg} / \mathrm{kg}$ of the extract, group 2 received $400 \mathrm{mg} / \mathrm{kg}$ of the extract, Group 3 received $800 \mathrm{mg} / \mathrm{kg}$, Group 4 received $5 \mathrm{mg} / \mathrm{kg}$ of Gliben clamide as positive control and Group 5 received distilled water only as the negative control.The extract was administered to the animals everyday for a duration of 2 weeks. Blood samples were withdrawn from the tail vein of each animal at Day 0, 7 and 14 and their blood sugar level determined and recorded using Accu-check glucometer (Odoh et al., 2014).

\subsubsection{Determination of the Antidiabetic Effect of the Methanol Root Extract of Strophanthus Hispidus on Fasting Blood} Sugar Level on Alloxan-Induced Diabetic Rats

Twenty-five (25) healthy albino divided into five groups of five animal in each were used for the experiment. The animal wasallowed free access to food and water and after 3 days animals whose blood glucose level were above $200 \mathrm{mg} / \mathrm{dl}$ were selected and divided into five groups $(\mathrm{n}=5)$. Group 1 received $200 \mathrm{mg} / \mathrm{kg}$ of the extract, Group 2 received $400 \mathrm{mg} / \mathrm{kg}$ of the extract, Group 3 received $800 \mathrm{mg} / \mathrm{kg}$ of the extract, Group 4 received $5 \mathrm{mg} / \mathrm{kg}$ of Glibenclamide as a positive control and group 5 received distilled water (negative control).

The extract was administered to the diabetic animals everyday for a duration of 2 weeks. Blood samples were withdrawn from the vein of each animal at Day 0, 7 and 14 and their blood sugar level determined and recorded using Accu-Check glucometer (Odoh et al., 2014).

\subsection{Determination of Pathological Parameters}

For pathological studies, blood was collected from all groups via the retro-orbital plexus using a capillary tube into an empty EDTA container which was placed into a test tube and centrifuged for 10 minutes at $3000 \mathrm{rpm}$ for separation of serum. This was done for each group of the animal at Day 0 and 14 for both normal and diabetic animals and the clear serum was then used for the analysis of pathological parameters; alanine aminotransferase (ALT), aspartate aminotransferase (AST), alkaline phosphatase (ALP), Creatinine and urea.

\subsubsection{Assay of Alanine Aminotransferase (ALT)}

A Randox commercial Enzyme kit based on the methods of Reitman and Frankel (1957) and Schmidt and Schmidt (1963) was used. Alanine aminotransferase assay is based on the principle that pyruvate is formed: $\propto$-ketoglutarate + L- alanine $\rightarrow$ L-glutamate + pyruvate. Alanine aminotransferase is measured by monitoring the concentration of pyruvate hydrazine formed with 2, 4-di-nitrophenyl hydrazine.

Reagent composition: Buffer (Reagent 1) - phosphate buffer (100 mmol/l pH 7.4), L-alanine (200 mmol/l), $\propto$-oxoglutarate $(2.0 \mathrm{mmol} / \mathrm{l})$.

Regent 2-2, 4-dinitrophenyl hydrazine $(2.0 \mathrm{mmol} / \mathrm{l})$ and sodium hydroxide solution $(0.4 \mathrm{~mol} / \mathrm{l})$.

The ALT substrate buffer ( $0.5 \mathrm{ml}$ each) was pipette into two sets of test tubes labeled B (sample blank) and T (sample test) respectively. The Serum $(0.1 \mathrm{ml})$ sample was added to the sample test $(\mathrm{T})$ only and mixed properly, then incubated for exactly $30 \mathrm{~min}$ in a water bath at a temperature of $37^{\circ} \mathrm{C} .0 .5 \mathrm{ml}$ of reagent 2 was added to both test tubes labeled T (sample 
test) and B (sample blank) immediately after the incubation. Also, $0.1 \mathrm{ml}$ of serum sample was added to the sample blank (B) only. The entire medium was mixed thoroughly and allowed to stand for exactly $20 \mathrm{~min}$ at $20-25^{\circ} \mathrm{C}$, after which, $5.0 \mathrm{ml}$ of sodium hydroxide $(\mathrm{NaOH})$ solution $(0.4 \mathrm{~mol} / \mathrm{l})$ was added to both test tubes and also mixed thoroughly. Absorbance of the sample was read at a wavelength of $550 \mathrm{~nm}$ after $5 \mathrm{~min}$ against the blank.

\subsubsection{Assay of Aspartate Aminotransferase (AST)}

A Randox commercial Enzyme kit according to the method of Reitman and Frankel (1957) and Schmidt and Schmidt (1963) was used.

This method is based on the principle that oxaloacetate is formed from the reaction below:

$\propto$-Oxoglntarate + L-aspartate $\rightarrow$ L-glutamate + Oxaloacetate Glutamic C-oxaloacetate hydrazone formed with 2,4dinitrophenyl hydrazine.

Reagent composition and procedure is the same as that of ALT (Alanine aminotransferase).

\subsubsection{Assay of Alkaline Phosphatase}

This was done using Teco Diagnostic kit which is based on the colometric endpoint method.The alkaline phosphatase acts upon the AMP-buffered sodium thymolphthalein monophosphate. The addition of an alkaline reagent stops enzyme activity and simultaneously develops a blue chromogen, which is measured photometrically.

Reagent composition:

- Alkaline phosphates substrate: $3.6 \mathrm{mM}$, sodium Thymolphthalein monophosphates in 0.2M 2-Amino-2-methyl-1propanol buffer. Magnesium chloride, $1.0 \mathrm{mM}$, wetting agent, inactive ingredients, preservatives; $\mathrm{pH} 10.2 \pm 0.1$.

- Alkaline phosphatase colour developer: $0.1 \mathrm{M}$ sodium hydroxide, $0.1 \mathrm{M}$ sodium carbonate.

- Alkaline phosphatase standard: Thymolphthalein in n-propanol $0.5 \mathrm{mM} / \mathrm{l}$. equivalent to $50 \mathrm{u} / \mathrm{l}$ enzyme activity when used according to the Alkaline phosphatase procedure.

For each sample, $0.5 \mathrm{ml}$ of Alkaline phosphatase substrate was dispensed into labeled test tubes and equilibrated to $37^{\circ} \mathrm{C}$ for 3 minutes. At timed intervals, $0.05 \mathrm{ml}$ of each standard, control and sample was added to its respective tubes. It was mixed gently. Deionized water was used as a blank. The test tubes were incubated for 10 minutes at $37^{\circ} \mathrm{C}$ following the same sequence, $2.5 \mathrm{ml}$ Alkaline phosphatase colour developer was added at time intervals and was mixed well. The wavelength of the Spectrophotometer was set at $590 \mathrm{~nm}$. Reagent blank was used to zero the machine. The absorbance of the samples was read and recorded. The activity of alkaline phosphatase in the serum was obtained from the formular below:

Concentration of sample $=\frac{\text { Absorbance of sample }}{\text { Absobance of standard }} \times$ concentration of standard

\subsubsection{Urea Determination}

Randox method was adapted. A $10 \mu \mathrm{l}$ of the serum sample was pipette into a labeled test tube T(sample test). A 10 $\mu l$ of the standard was introduced into a labeled test tube B (Standard test - 0.14N Sodium hydroxide). A $10 \mu l$ distilled water was pipette into a labeled test tube C (Blank test). A $100 \mu$ lof Reagent 1 ( $6 \mathrm{mmol} / \mathrm{l}$ sodium nitroprusside, $1 \mathrm{~g} / \mathrm{l}$ urease) was added to test tubes labeled $\mathrm{T}$ (sample test), B (standard test) and C (Blank test) and the test tubes were incubated for 10 minutes at $37^{\circ} \mathrm{C}$. A $2.50 \mathrm{ml}$ of Reagent $2(120 \mathrm{mmol} / \mathrm{l} \mathrm{Phenol})$ and $2.50 \mathrm{ml}$ of Reagent $3(27 \mathrm{mmol} / \mathrm{l}$ Sodium hypochlorite) were added to each test tubes and mixed properly and incubated at $37^{\circ} \mathrm{C}$ for 15 minutes. The absorbance of the sample and standard was read as against the blank and record at a wavelength of $546 \mathrm{~nm}$ using a colorimeter.

$$
\text { Urea concentration }=\frac{\text { sample }}{\text { standard }} \mathrm{X} \text { standard conc. }
$$

\subsubsection{Creatinine Determination}

Creatinine in alkaline solution reacts with picric acid to form a coloured complex. The amount of the complex formed is directly proportional to the creatinine concentration. Standard, working reagent is picric acid (35mmol/l) and sodium hydroxide $(0.32 \mathrm{~mol} / \mathrm{l})$. A $2.0 \mathrm{ml}$ of the working reagent was pipette into two sets of test tubes labeled C (standard test) and T (sample test) respectively. $0.2 \mathrm{ml}$ of the standard solution was added to the standard test (C) only and mixed properly. The serum $(0.2 \mathrm{ml})$ sample was added to the sample test $(\mathrm{T})$ only. Mixed and incubated at $37^{\circ} \mathrm{C}$ and after 30 seconds the absorbance $A_{1}$ of the standard and sample were read. At exactly 2 minutes later the absorbance $A_{2}$ of standard and sample was read and recorded.

$\mathrm{A}_{2}-\mathrm{A}_{1}=\Delta \mathrm{A}$ sample or $\Delta \mathrm{A}$ standard

Creatinine concentration $=\frac{\Delta \mathrm{A} \text { Sample }}{\Delta \mathrm{A} \text { Standard }} \mathrm{X}$ standard conc.

\subsection{Statistical Analysis}

Results were analysed by SPSS (version 16) using one-way ANOVA and further subjected to Dunnet post hoc test and expressed as meant \pm SEM. Difference between means of treated and control were considered significant at $\mathrm{P}<0.05$. 


\section{Results}

\subsection{Percentageyield of extract}

The percentage yield of the extract is $4.43 \%$.

\subsection{Results of Phytochemical Analysis} Table 1.

The results of the phytochemical analysis of the methanol root extract of Strophanthus hispidusis as shown in

\begin{tabular}{|c|c|}
\hline Test & Methanol extract \\
\hline Saponins & ++ \\
\hline Glycosides & ++ \\
\hline Proteins & + \\
\hline Steroids & + \\
\hline Terpenoids & + \\
\hline Reducing sugars & ++ \\
\hline Tannins & ++ \\
\hline Carbohydrates & +++ \\
\hline Flavonoids & - \\
\hline Alkaloids & - \\
\hline Fats and Oils & + \\
\hline Acid compounds & + \\
\hline
\end{tabular}

Table 1: Result of the Chemical Classes Present in the Methanol Root Extract of

Strophanthus Hispidus

Key: ++ +: High in Concentration + +: Moderate in Concentration +: Low In Concentration -: Absent

\subsection{Results of Acute Toxicity Studies}

The oral $\mathrm{LD}_{50}$ of the methanol root extract of Strophanthus hispidus was found to be $>5000 \mathrm{mg} / \mathrm{kg}$ (Table 2).

\begin{tabular}{|c|c|c|c|}
\hline Phase I & Dose $\mathbf{( m g} / \mathbf{k g})$ & No of Animals & No of Deaths \\
\hline & 10 & 3 & $0 / 3$ \\
\hline & 100 & 3 & $0 / 3$ \\
\hline & 1000 & 3 & $0 / 3$ \\
\hline Phase II & 1600 & 2 & $0 / 2$ \\
\hline & 2900 & 2 & $0 / 2$ \\
\hline & $5,000 \quad 2$ & \\
\hline
\end{tabular}

Table 2: Result of the Acute Oral Toxicity $\left(L D_{50}\right)$ of the Methanol Root Extract of Strophanthus Hispidus

\subsection{Results of the Antidiabetic Evaluation}

The results of the blood sugar level of the antidiabetic effect of the methanol root extract of strophanthus hispidus on normal and alloxan-induced diabetic rats are asshown in Tables 3 and 4.

\begin{tabular}{|c|c|c|c|c|c|}
\hline Treatment & Dose(mg/kg) & \multicolumn{2}{|c|}{ Mean Blood Sugar (MBS) Level (mg/dl) } & $\begin{array}{c}\text { Percentage } \\
\text { Maximum } \\
\text { Deduction (\%) }\end{array}$ \\
\cline { 2 - 6 } & & Day 0 & Day 7 & $87.20 \pm 1.07$ & 1.80 \\
\hline $\begin{array}{c}\text { Distilled Water } \\
\text { (ml/kg). }\end{array}$ & - & $88.80 \pm 0.58$ & $57.80 \pm 0.86$ & & 39.78 \\
\hline Glibenclamide & 5 & $89.00 \pm 1.30$ & $63.60 \pm 1.60^{*}$ & $53.60 \pm 1.69$ & 27.59 \\
\hline \multirow{2}{*}{ Extract } & 200 & $92.80 \pm 1.77$ & $81.40 \pm 2.25$ & $67.20 \pm 4.49$ & 34.28 \\
\cline { 2 - 6 } & 400 & $91.60 \pm 2.34$ & $79.60 \pm 0.51^{*}$ & $60.20 \pm 2.67$ & 41.92 \\
\cline { 2 - 6 }
\end{tabular}

Table 3: Result of the Effect of the Methanol Root Extract of Strophanthushispidus on Normal Rats

Values Are Expressed as Mean $\pm S E M ;{ }^{*} P<0.05 ; N=5$ 


\begin{tabular}{|c|c|c|c|c|c|}
\hline \multirow{2}{*}{ Treatment } & Dose(mg/kg) & \multicolumn{2}{|c|}{ Mean Blood Sugar (MBS) Level (mg/dl) } & $\begin{array}{c}\text { Percentage } \\
\text { Maximum } \\
\text { Reduction (\%) }\end{array}$ \\
\cline { 2 - 6 } & & Day 0 & Day 7 & Day 14 & - \\
\hline $\begin{array}{c}\text { Distilled water } \\
\text { (ml/kg) }\end{array}$ & - & $248.00 \pm 2.41$ & - & - & 67.74 \\
\hline Glibenclamide & 5 & $241.20 \pm 10.30$ & $163.20 \pm 5.71$ & $77.80 \pm 1.86^{*}$ & 64.72 \\
\hline \multirow{3}{*}{ Extract } & 200 & $254 \pm 10.28$ & $157.00 \pm 4.25$ & $89.60 \pm 1.50$ & 67.69 \\
\cline { 2 - 6 } & 400 & $247.00 \pm 4.61$ & $227.40 \pm 22.02$ & $79.80 \pm 2.59$ & 69.43 \\
\hline
\end{tabular}

Table 4: Result of the Effect of Methanol Root Extract of Strophanthus Hispidus on the

Blood Sugar Level of Alloxan-Induced Diabetic Rats

Values Are Expressed as Mean $\pm S E M ;{ }^{*} P<0.05 ; N=5$

\subsection{Results of the Pathological Evaluation}

The basal pathological parameters at day 0 before administration (basal) and after treatment with the methanol root Extract of Strophanthus hispidus andglibenclamide on normal ratsand alloxan induced diabetic rats are shown in Tables 5, 6 and 7/ (Table 5).

\begin{tabular}{|c|c|c|c|c|c|c|}
\hline Treatment & $\begin{array}{c}\text { Dose } \\
(\mathbf{m g} / \mathbf{k g})\end{array}$ & \multicolumn{5}{|c|}{ Mean of Pathological Parameters at Day 0 } \\
\cline { 3 - 7 } & & ALT (IU/L) & AST (IU/L) & ALP(IU/L) & Urea(mg/dl) & $\begin{array}{c}\text { Creatinine } \\
\text { (mg/dl) }\end{array}$ \\
\hline $\begin{array}{c}\text { Distilled water } \\
\text { (kg) }\end{array}$ & - & $10.75 \pm 0.85$ & $16.00 \pm 1.96$ & $95.75 \pm 4.07$ & $19.00 \pm 3.37$ & $0.54 \pm 0.07$ \\
\hline Glibenclamide & 5 & $14.50 \pm 2.85$ & $13.00 \pm 1.96$ & $95.75 \pm 8.14$ & $15.50 \pm 2.90$ & $0.67 \pm 0.09$ \\
\hline \multirow{3}{*}{ Extract } & 200 & $15.50 \pm 2.22$ & $13.75 \pm 1.93$ & $73.00 \pm 11.67$ & $12.25 \pm 3.52$ & $0.44 \pm 0.03$ \\
\cline { 2 - 7 } & 400 & $12.00 \pm 1.47$ & $16.00 \pm 1.96$ & $57.75 \pm 4.91$ & $14.25 \pm 3.75$ & $0.63 \pm 0.03$ \\
\cline { 2 - 7 } & 800 & $22.00 \pm 3.39$ & $15.25 \pm 1.65$ & $60.25 \pm 8.22$ & $13.50 \pm 4.56$ & $0.55 \pm 0.03$ \\
\hline
\end{tabular}

Table 5: Result of the Basal Pathological Parameters before Induction of diabetes Values Are Expressed as Mean $\pm S E M ; P<0.05 ; N=4$

\begin{tabular}{|c|c|c|c|c|c|c|}
\hline \multirow[t]{2}{*}{ Treatment } & \multirow{2}{*}{$\begin{array}{l}\text { Dose } \\
(\mathrm{mg} / \mathrm{kg})\end{array}$} & \multicolumn{5}{|c|}{ Mean of pathological parameters at day 0} \\
\hline & & ALT (IU/L) & AST (IU/L) & ALP(IU/L) & Urea(mg/dl) & $\begin{array}{l}\text { Creatinine } \\
\text { (mg/dl) }\end{array}$ \\
\hline $\begin{array}{l}\text { Distilled water } \\
(\mathrm{ml} / \mathrm{kg})\end{array}$ & - & $58.50 \pm 2.02$ & $26.75 \pm 2.92$ & $51.50 \pm 3.66$ & $41.75 \pm 1.49$ & $0.84 \pm 0.06$ \\
\hline Glibenclamide & 5 & $46.50 \pm 4.97$ & $20.75 \pm 1.65$ & $61.75 \pm 2.29$ & $39.68 \pm 1.86$ & $0.29 \pm 0.04$ \\
\hline \multirow{3}{*}{ Extract } & 200 & $59.75 \pm 4.51$ & $22.50 \pm 1.89$ & $46.50 \pm 4.05$ & $36.35 \pm 0.57$ & $0.71 \pm 0.05$ \\
\hline & 400 & $51.75 \pm 7.69$ & $27.50 \pm 1.55$ & $37.00 \pm 3.39$ & $40.95 \pm 0.92$ & $0.44 \pm 0.93$ \\
\hline & 800 & $82.50 \pm 4.41$ & $25.25 \pm 1.25$ & $39.75 \pm 1.44$ & $44.00 \pm 0.88$ & $0.37 \pm 0.03$ \\
\hline
\end{tabular}

Table 6: Result of the Effect of the Methanol Root Extract of Strophanthus Hispiduson the Pathological Parameters of Alloxan-Induced Diabetic Rats at Day 0

Values Are Expressed as Mean \pm SEM; $P<0.05 ; N=4$

\begin{tabular}{|c|c|c|c|c|c|c|}
\hline \multirow[t]{2}{*}{ Treatment } & \multirow{2}{*}{$\begin{array}{c}\text { Dose } \\
\text { (mg/kg) }\end{array}$} & \multicolumn{5}{|c|}{ Mean of pathological parameters at Day 14} \\
\hline & & ALT (IU/L) & AST (IU/L) & $\operatorname{ALP}(\mathrm{IU} / \mathrm{L})$ & Urea(mg/dl) & $\begin{array}{c}\text { Creatinine } \\
\text { (mg/dl) }\end{array}$ \\
\hline $\begin{array}{c}\text { Distilled } \\
\text { water } \\
(\mathrm{ml} / \mathrm{kg})\end{array}$ & - & $28.75 \pm 5.69$ & $21 . .01 \pm 1.55$ & $68.00 \pm 2.48$ & $25.05 \pm 5.32$ & $0.62 \pm 0.04$ \\
\hline $\begin{array}{c}\text { Glibenclamid } \\
\mathrm{e}\end{array}$ & 5 & $39.00 \pm 3.16$ & $18 . .50 \pm 1.50$ & $53.75 \pm 1.25$ & $18.95 \pm 1.82$ & $0.34 \pm 0.03$ \\
\hline \multirow{3}{*}{ Extract } & 200 & $35.75 \pm 5.57$ & $17.32 \pm 1.31$ & $57.25 \pm 4.09$ & $17.60 \pm 1.05$ & $0.64 \pm 0.07$ \\
\hline & 400 & $65.00 \pm 3.29$ & $20.50 \pm 1.55$ & $42.25 \pm 4.19$ & $16.31 \pm 0.54$ & $0.43 \pm 0.06$ \\
\hline & 800 & $88.00 \pm 3.70$ & $16.40 \pm 0.29$ & $49.00 \pm 1.35$ & $14.60 \pm 1.07$ & $0.37 \pm 0.74$ \\
\hline
\end{tabular}

Table 7: Results of the Effect of the Methanol Root Extract of Strophanthus

Hispidus on the Pathological Parameters of alloxan-Induced Diabetic Rats after 14 Days

Values Are Expressed as Mean \pm SEM; $P<0.05 ; N=4$ 


\section{Discussion}

The yield of the extraction was appreciable (4.43\%) showing that methanol was a good solvent for extracting the constituents from the roots.From the results of phytochemical analysis, it was found that the plant extract contains many chemical constituents which include: alkaloids, flavonoids, tannins, steroids, terpenoids reducing sugars, carbohydrates, proteins, glycosides and saponins. Some plants that contain alkaloids have been reported to have hypoglycaemic activity (Bever and Zahad, 1979). So, the anti-diabetic activity associated with Strophanthus hispidus root extract may be attributed to the presence of this alkaloids and flavonoids. These are mainly phenolic compounds which have been reported to have anti-diabetic effects (Farjou, et al., 1987).

From the results of acute toxicity test, it shows that it was non-toxic, as at the dose of 5,000 $\mathrm{mg} / \mathrm{kg}$ no death was recorded and can be used at the studied doses in management of ailments.

The administration of the crude methanol roots extract of Strophanthus hispidusat doses of 200,400 and $800 \mathrm{mg} / \mathrm{kg}$ body weight $(\mathrm{P}<0.05)$ showed that the extract exhibited significant reduction in the blood sugar level in both the normoglycaemic and hyperglycaemic rats. In the normal rats, the doses of 200,400 and $800 \mathrm{mg} / \mathrm{kg}$ of the extract caused a percentage maximum reduction of $27.59,34.28$ and $41.92 \%$ respectively after 14 days while in the alloxan induced diabetic rats, the doses of 200,400 and $800 \mathrm{mg} / \mathrm{kg}$ of the extract caused a percentage maximum reduction of $64.72,67.69$ and $69.43 \%$ after 14 days of treatment. Thus, the 200,400 and $800 \mathrm{mg} / \mathrm{kg}$ doses of the extract have comparable antidiabetic activity to $5 \mathrm{mg} / \mathrm{kg}$ dose of glibenclamide (xx).

This study reveals the effect of the methanol root extract on pathological parameters. Alanine aminotransferase (ALT) is a liver specific and kidney specific enzyme while aspartate aminotransferase (AST) is found in the heart, liver, skeletal muscle and kidney. Alkaline Phosphatase (ALP) is found mainly in the liver and bones. Creatinine is produced by the muscle. There was significant $(p<0.05)$ increase in the liver enzymes level in the diabetic rats on day 0before the administration of the extract. At day 14 in the alloxan-induced diabetic rats, there was a significant $(p<0.05)$ decrease in the liver enzymes at studied doses $(200,400$ and $800 \mathrm{mg} / \mathrm{kg})$ when compared to the normal. There was significant $(\mathrm{p}<$ 0.05 ) difference in the AST level at day 14 when compared to day 0 in alloxan-induced diabetic rats. At the doses extract, there was a significant decrease in the ALP level when compared to the normal at day 0. Also, the extract has the effect of decreasing the urea level at a dose of 200,400 and $800 \mathrm{mg} / \mathrm{kg}$ from $36.35,40.95$ and $41.00 \mathrm{mg} / \mathrm{dl}$ at day 0 to $17.60,16.31$ and $14.60 \mathrm{mg} / \mathrm{dl}$ at day 14 . The level was similarly reduced for the positive group (Glibenclamide).At day 14 there was a decrease in the urea level in the diabetic rats when compared to day 0 . The methanol root extract has no significant effect in the creatinine level.

\section{Conclusion}

The root of Strophanthus hispidus do possessanti-diabetic effectas evidenced in the results of both the normal and alloxan induced diabetic rats. There was also a significant effect on the pathological parameters

\section{Recommendation}

Further studies are required towards isolating, purifying and characterizing these bio-active phytoconstituents of Strophanthus hispidus responsible for this activity.

\section{References}

i. Ayoola, G.A, Folawewo, A.O, Adesegun, S.A and Abioro, O.0. (2008). Phytochemical and antioxidant screening of some plants of Apocynaceae from South West Nigeria. African Journal of Plant Science Vol. 2(9), pp. 124-128.

ii. Bever, B.0 and Zahad, G.R. (1979). Plants with Oral Hypoglycaemic Action. J. Crude Res. 17: 139-196.

iii. Chattopadhyay, R. R. (1996). Possible mechanism of antihyperglycaemic effect of Azadirachta indica leaf extract, part IV. Gen Pharmacol. 27: 431-434

iv. Dandu, A.M.and Inamdar, N. M. (2009). Evaluation of beneficial effects of antioxidant properties of aqueous leaf extract of Andrographis paniculatain STZinduced diabetes. Pak J Pharm Sci, 22, 49-52.

v. David, G. and Gardner, D. (2011). Greenspan's basic and Clinical endocrinology. $9^{\text {th }}$ ed. New York: McGraw-Hill medical.

vi. Eddouks, M., Lemhadri, A., Zeggwagh, N. A., Michel, J. B. (2005). Potent hypoglycaemic activity of the aqueous extract of Chamaemelum nobite in normaland streptozotocin-induced diabetic rats. Diabetes Res Clin Pract, 67, 189-195.

vii. Eidi, A., Eidi, M., Esmaeili, E. (2006). Antidiabetic effect of garlic (Allium sativum L.) in normal and streptozotocininduced diabetic rats. Phytomedicine; 13(9-10):624-629. [PMID:17085291].

viii. Farjou, I.B., Al-Ani, M. and Guirges, S.Y. (1987). Lowering of Glucose Blood in Diabetes rabbits by Artemisia Extract. Faculty med. Baghdad. 92:137-141.

ix. Ishola, I.O., Awodele, O., Oreabga, I. A., Murtala, A. A., Chijioke, M. C. (2013). Antinociceptive, anti-inflammatory and antiulcerogenic activities of ethanol root extract of Strophanthus hispidus DC (Apocynacae). Journal of Basic and Clinical Physiology and Pharmacology. 24(4): 277-286.

x. Kumar, V., Abbas, A., Fausto, N. and Aster, J. (2005). Robbins and Cotran Pathologic Basis of Disease. $7^{\text {th }}$ ed., Philadelphia, Pa.; Saunders. Pp. 1194-1195. ISBN 0-7216-0817-1.

xi. Lorke,D. (1983). A New Approach to Practical Acute Toxicity testing. Archives of Toxicology. 54: 275-287.

xii. Osadebe,P.O, Odoh, U.E. and Uzor, P.F. (2014). Medicinal Plants with investigatedantidiabetic potentials. African Journal of Pharmacy and Pharmacology. 8(11): 292-303. 
xiii. Odoh, U. E.,Onugha, V. O., Chukwube, V. O. (2016). Evaluation of antidiabetic effect and hematotological profile of methanol extract of Ceiba pentandra G (Malvaceae) stem bark on alloxan-induced diabetic rats. African Journal of Pharmacy and Pharmacology, 10(28): 584-590.

xiv. Odoh, U. E., Ndubuokwu, R. I., Inya-Agha, S. I., Osadebe, P.O., Uzor, P. F., Ezejiofor, M. (2014). Antidiabetic activity and Phytochemical Screening of Acalypha wilkesiana (Euphorbiaceae) Mull Arg. roots in alloxan-induced diabetic rats. Sci Res Essay 2014,9(7): 204-212.

xv. Odoh, U. E., Ezugwu, C.O. and Ezejiofor, M. (2013).Anti-diabetic and toxicological studies of the alkaloids of Acanthus montanus (Acanthaceae) leaf.International Journal of Current Research,Vol. 5 (12): 4249-4255.

xvi. Reitman S.and Frankel S. (1957). A colorometric method for the determination of serum glutamic oxaloacetic and glutamic pyruvic transaminase. Am. J. Clin. Pathol. 28:56-63.

xvii. Seema, P.V., Sudha, B., Padayatti, .P.S. (1996). Kinetic studies of purified malate deshydrogenase liver of streptozotocin-diabetic rats and the effect of leaf extract of Aegle marmelose(L.) Correa ex Roxb. IndianJ Exp Biol. 34: 600-602

xviii. Schmidt, E.and Schmidt F.W (1963). Determination of Serum glutamic oxaloacetic and glutamic pyruvic transaminase. Enzyme Biological Clinic 3:1-5.

xix. Smyth, S.and Heron, A. (2006). 'Diabetes and obesity: the twin epidemics'Nature Medicine 12(1): 75-80 PMID 16397575.

xx. Thirumalai, T., Therasa, V.S., Elumalai, E. K., David, E. (2011). Hypoglycemic effect of Brassica juncea(seeds) on streptozotocin induced diabetic male albino rat. Asian Pac J Trop Biom; 323-325.

xxi. Trease, G. and W.C. Evans, (1989). A Textbook of Pharmacognosy. 13 ${ }^{\text {th }}$ edn., W.B. Saunders, London. Pp: 176-180.

xxii. Yasir, M., Jain, P., Debajyoti, D. and Kharya, M.D. ( 2010) Hypoglycemic and antihyperglycemic effect of different extracts of Acacia arabica lamk bark in normal and alloxan induced diabetic rats, Int. J. Phytomed.; 2,133-138.

xxiii. WHO. (2013). Diabetes fact Sheet No312.', Retrieved 25th March 2014. 